\title{
RESEARCH
}

Open Access

\section{Species richness, forest types and regeneration of Schima in the subtropical forest ecosystem of Yunnan, southwestern China}

Cindy Q. Tang ${ }^{1 *} \mathbb{D}$, Peng-Bin Han ${ }^{1 *}$, Shuaifeng Li ${ }^{2}$ Li-Qin Shen ${ }^{1}$, Diao-Shun Huang ${ }^{1}$, Yun-Fang Li ${ }^{3}$, Ming-Chun Peng ${ }^{1}$, Chong-Yun Wang ${ }^{1}$, Xiao-Shuang $\mathrm{Li}^{4}$, Wei Li ${ }^{1}$, Wei Wang ${ }^{5}$ and Zhi-Ying Zhang ${ }^{1}$

\begin{abstract}
Background: Schima genus of Theaceae is confined to subtropics and tropics of South, East and Southeast Asia. Thirteen species of Schima are distributed in subtropical China. Many of them appear as dominant canopy species in the subtropical forests. To date, Schima species richness distribution patterns of China have remained unknown. Meanwhile, there has been a longtime debate as to whether forests dominated by Schima species are early or late successional forests. We aim to clarify Schima species richness patterns and these species' roles in the forest succession and regeneration dynamics of the subtropical ecosystem in Yunnan Province, China.

Method: We mapped Schima species richness distribution patterns in China. Based on 71 vegetation plots, we analyzed forest characteristics, population structure, and regeneration dynamics of Schima species in Yunnan.

Results: Yunnan was found to harbor the greatest richness and the highest rarity-weighted richness of Schima species in the subtropical regions of China. We classified five primary and six secondary forest types containing Schima species as one of dominants. Yunnan had the high floristic diversity and varying stand structure of forests containing Schima species. The Schima species studied generally had a sporadic regeneration type and a long lifespan. Four species (Schima argentea, Schima villosa, Schima sinensis, Schima sericans) were shade-intolerant. But three species (Schima noronhae, Schima khasiana and Schima wallichii) were considered as bi-modal type species having shade-intolerant and shade-tolerant traits. Schima noronhae was seen to be a top dominant in late successional forests, while S. wallichii was found as a top-dominant in early or middle or late successional forests. S. khasiana, Schima villosa, Schima sinensis usually appeared as a top dominant in early or middle successional secondary forests, though they also presented as a second dominant in late-successional forests. Schima argentea and Schima sericans dominated only in the early or middle/seral successional forests. Schima species' regeneration establishment depended mainly on forest canopy gap formation through moderate human and natural disturbances.

(Continued on next page)
\end{abstract}

\footnotetext{
*Correspondence: cindyqtang@aol.com; baqidehan@qq.com

1 Institute of Ecology and Geobotany, College of Ecology and Environmental

Science, Yunnan University, Kunming 650504, China

Full list of author information is available at the end of the article
}

\section{Springer Open}

(c) The Author(s). 2020 Open Access This article is licensed under a Creative Commons Attribution 4.0 International License, which permits use, sharing, adaptation, distribution and reproduction in any medium or format, as long as you give appropriate credit to the original author(s) and the source, provide a link to the Creative Commons licence, and indicate if changes were made. The images or other third party material in this article are included in the article's Creative Commons licence, unless indicated otherwise in a credit line to the material. If material is not included in the article's Creative Commons licence and your intended use is not permitted by statutory regulation or exceeds the permitted use, you will need to obtain permission directly from the copyright holder. To view a copy of this licence, visit http://creativecommons.org/licenses/by/4.0/. 


\begin{abstract}
(Continued from previous page)
Conclusions: Yunnan has high species richness and rarity-weighted richness of Schima. Both moderate human and natural disturbances have provided regeneration niches for Schima species. Some of the Schima species studied as a second dominant (rare as the top-dominant) present in the late-successional forests. Some of them are more often as the top-dominant in early or middle successional forests, where as time goes by the dominance of Schima species would be replaced by their associated dominant taxa such as Castanopsis species.
\end{abstract}

Keywords: Forest structure, Regeneration dynamics, Schima, Species richness, Forest succession, Yunnan

\section{Background}

Schima, a genus belonging to Theaceae, is widely distributed in the eastern Himalaya of Nepal, Bhutan, northeastern India, Bangladesh and northern Myanmar, Indochina (Thailand, Cambodia, Laos, and Vietnam), southern China, Japan (Ryukyu Archipelago and Ogasawara Islands), Malaysia, Indonesia and Brunei (Fig. 1a, Table 1). Fossil species of Schima have been found from the Miocene of Germany (Mai 1971), Yunnan of China (Li et al. 2013a), Japan (Choi et al. 2010), Styria of Austria (Kovar-Ender and Hably 2006) and the Oligocene of Guangxi of China (Shi et al. 2017). Recent molecular phylogenetic analysis showed Schima is closely related to Gordonia and Franklinia, forming the monophyletic tribe of Gordoniae (Prince and Parks 2001; Li et al. 2013b; Zhang et al. 2014). There has been an argument as to the number of species of Schima (Prince 2007). For example, Bloembergen (1952) recognized only one species, Schima wallichii with nine subspecies and three varieties. Airy Shaw (1985) mentioned that Schima has 15 species. Min and Bartholomew (2007) and Byng (2014) reported that there are about 20 species. We adapt Min and Bartholomew (2007) that 13 species present in China; among them 6 species are endemic to China. Most of the 13 species occur as one of dominants with some species of other genera in the subtropical evergreen broad-leaved forest ecosystem of China. The evergreen broad-leaved forests of China are generally found in large, discontinuous patches in the subtropical zone of China. However, due to human intensive activities on the subtropical ecosystem many primeval evergreen broad-leaved forests were replaced by secondary vegetation in China (Wu 1980; Tang 2015a, b).

Among the Schima species of China, Schima superba which widely distributed in the eastern subtropical regions of China, has been studied from aspects of its forest communities (e.g. Wang and Li 1999; Yang et al. 2006; Song 2007), population structure (e.g. Cai and Song 1997; Hu 2005; Li et al. 2008) and genetics (e.g. Zhang et al. 2006; Jin et al. 2007). In contrast, to date the knowledge on the other species of Schima is very scarce. It is critical to elucidate spatial patterns of species richness of the genus and ecological role of other Schima species in forest succession and regeneration dynamics of the subtropical ecosystem.

There has been a longtime debate as to whether forests dominated by Schima species are early or late successional forests. Eight species of Schima are distributed in Yunnan, southwestern China. Yunnan affords us a unique opportunity to explore forests containing Schima species as one of the dominants in various landscape contexts. Understanding species richness patterns, forest types and regeneration characteristics of Schima are a prerequisite to understand the dynamics of the forests and provide a reference for forest reforestation and site restoration programs. We address the following questions: (1) How are the distribution patterns of species richness of Schima in Yunnan as compared with those in other regions of subtropical China? (2) What are the forest types and structure dominated by Schima species? (3) What are the regeneration dynamics of Schima species in Yunnan?

\section{Methods}

Study area

Yunnan is a highland province $\left(21^{\circ} 08^{\prime}-29^{\circ} 15^{\prime} \mathrm{N}\right.$, $97^{\circ} 31^{\prime}-106^{\circ} 11^{\prime}$ E) located in southwestern China, and having the greatest elevation difference on earth, from the northwest ( $6740 \mathrm{~m}$ a.s.l.) to the southeast (76 $\mathrm{m}$ a.s.l.). Set in the foothills of the Himalayas and Tibet, Yunnan's climate ranges from the icy highland climate of the northwestern frontier to the tropical lowland climate of the area bordering Myanmar and extending south and east toward Laos and Vietnam (Fig. 1b). The vegetation is from lowland tropical, to hilly/mid-elevational subtropical evergreen broad-leaved forests to alpine coldtemperate coniferous forests, scrubs, meadows and grasslands at the high altitudes. The Yunnan area is included in 'Indo-Burma' global hotspot of biodiversity (Myers et al. 2000). Most of the province falls into latitudes classified as middle subtropics $\left(25^{\circ} 00^{\prime}-29^{\circ} 15^{\prime} \mathrm{N}\right)$ and southern subtropics $\left(22^{\circ} 30^{\prime}-25^{\circ} 00^{\prime} \mathrm{N}\right)$. The small area between $21^{\circ} 08^{\prime}-22^{\circ} 30^{\prime} \mathrm{N}$ is considered as northernmost tropics. The climate is monsoonal, with rainy summers. The monsoon, moving mainly from the Bay of Bengal, causes heavy rainfall on the southern aspect of the plateau, then it diminishes northward, creating a rainfall gradient. About $80 \%$ of the rain falls during rainy season-summer, and the most of the remainder falls in autumn and spring, leaving the winter cool and dry. The subtropical forests of Yunnan are remarkable for their 

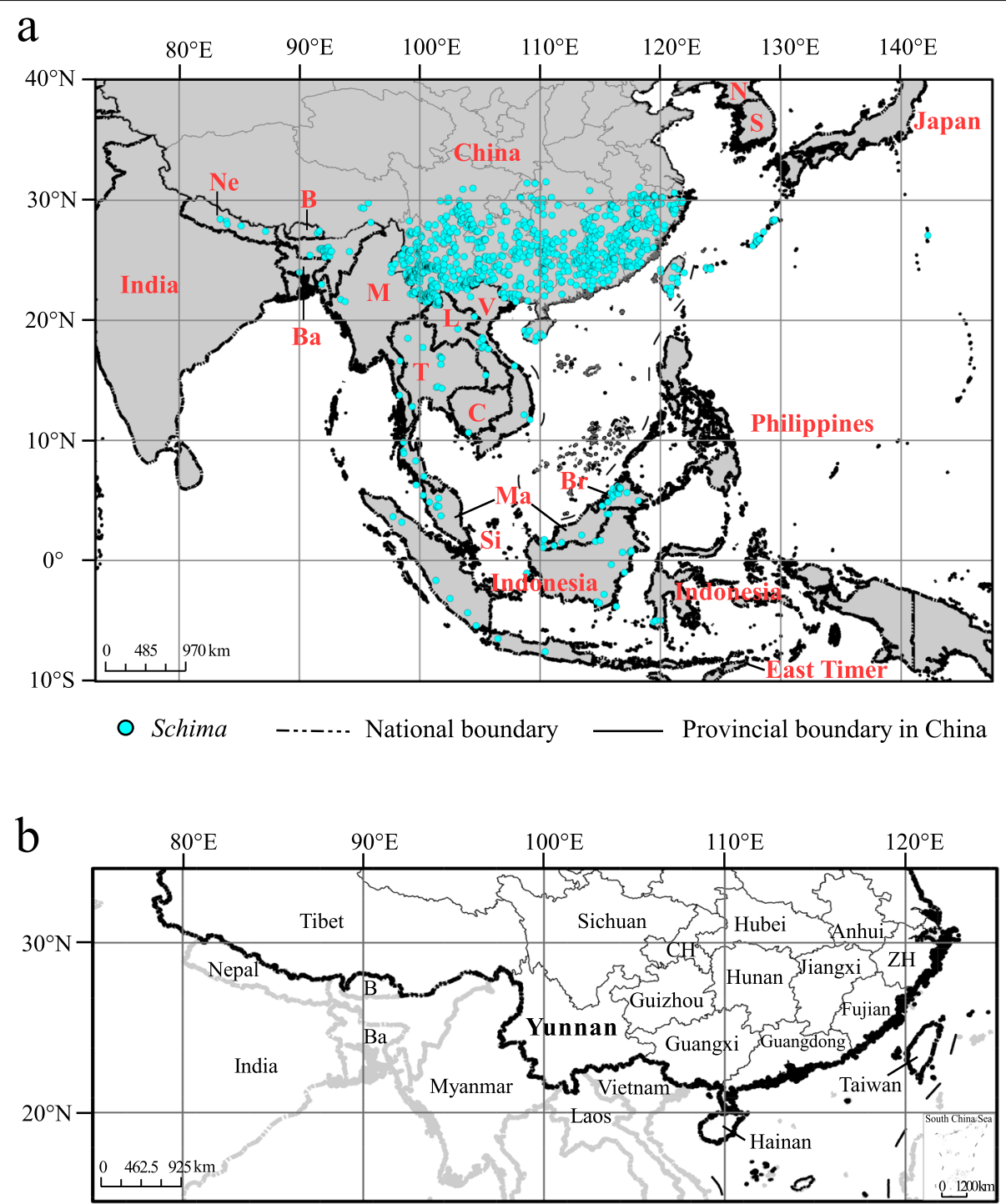

Fig. 1 Distribution of Schima genus in East Asia. a Distribution of Schima. $N=$ North Korea, $S=$ South Korea, Ne= Nepal, B = Bhutan, Ba = Bangladesh, M= Myanmar, $\mathrm{L}=\mathrm{Laos}, \mathrm{V}=$ Vietnam, $\mathrm{T}=$ Thailand, $\mathrm{C}=$ Cambodia, $\mathrm{Ma}=$ Malaysia, $\mathrm{Si}=$ Singapore, $\mathrm{Br}=$ Brunei. Data sources: this study, Chinese Virtual Herbarium database (http://www.cvh.org), GBIF database (www.gbif.org), International Union for Conservation of Nature database (www.iucnredlist.org). b The partial provinces of China where Schima is found. $\mathrm{CH}=$ Chongqing, $\mathrm{ZH}=$ Zhejiang.

globally high plant diversity and extraordinary local endemism and diverse plant communities (Tang 2015a).

\section{Study species}

We made efforts to study species of Schima in the wild in Yunnan Province. Among the thirteen Schima species of China, eight occur in Yunnan (Table 1). Since one (Schima brevipedicellata) of the eight species does not appear as a dominant in the forests, we exclude it. Thus, our focal species in this paper are seven species, i.e. Schima khasiana, Schima noronhae, Schima villosa, Schima sinensis, Schima wallichii, Schima sericans, Schima argentea, each of which is found as one of the dominants in the primary or secondary subtropical evergreen broad-leaved forests of Yunnan. Most of the seven species become quite tall (some can reach $45 \mathrm{~m}$ ). They have showy, fragrant white flowers, with five petals and numerous yellow stamens. The leaves are alternate, spirally arranged, and entire or crenate or serrate. Schima flowers are hermaphrodite, axillary and solitary, or rarely three to five flowers are crowded along a short raceme. The fruit is a woody, globose or subglobose capsule, which splits for half its length into (four to) five (to six) segments; a stout, central column remains. The seeds are small and kidney-shaped, flat, with a narrow marginal wing. Representative characteristics of the Schima species and their forest communities are shown in Figs. 2a-l. 
Table 1 Schima species of East Asia. Data Sources: this study, eFlora of China (http://flora.huh.harvard.edu/china/), Chinese Virtual Herbarium database (http://www.cvh.org), GBIF database (www.gbif.org) and International Union for Conservation of Nature (www.iucnredlist.org)

\begin{tabular}{|c|c|}
\hline Species & Distribution region \\
\hline Schima khasiana & $\begin{array}{l}\text { Yunnan, SE Tibet of China; Bhutan; NE India; N } \\
\text { Myanmar; N Vietnam }\end{array}$ \\
\hline Schima villosa & Yunnan of China \\
\hline Schima sinensis & $\begin{array}{l}\text { NE Yunnan, N Guangxi, Guizhou, western Hubei, } \\
\text { western Hunan, Sichuan of China }\end{array}$ \\
\hline Schima sericans & NW Yunnan, SE Tibet of China \\
\hline Schima argentea & $\begin{array}{l}\text { Yunnan, S Gaungxi, Jiangxi, SW Sichuan of China; } \\
\text { Myanmar; Vietnam of China; Myanmar; Vietnam }\end{array}$ \\
\hline $\begin{array}{l}\text { Schima } \\
\text { noronhae }\end{array}$ & $\begin{array}{l}\text { S Yunnan of China; Indonesia; Laos; Malaysia; } \\
\text { Myanmar; Thailand; Vietnam }\end{array}$ \\
\hline Schima wallichii & $\begin{array}{l}\text { S Yunnan, S Guangxi, S Guizhou, SE Tibet of China; } \\
\text { Bhutan; NE India; Bangladesh; Laos; Myanmar; Nepal; } \\
\text { Thailand; Vietnam; Japan (Ryukyu Islands); Indonesia; } \\
\text { Brunei; Cambodia }\end{array}$ \\
\hline $\begin{array}{l}\text { Schima } \\
\text { brevipedicellata }\end{array}$ & $\begin{array}{l}\text { SE Yunnan, NW Guangdong, N Guangxi, Guizhou, } \\
\text { Hunan, S Jiangxi, SE Sichuan of China; N Vietnam }\end{array}$ \\
\hline $\begin{array}{l}\text { Schima } \\
\text { multibracteata }\end{array}$ & E \& S Guangdong of China \\
\hline Schima crenata & $\begin{array}{l}\text { Hainan of China; Cambodia; Indonesia; Laos; Malaysia; } \\
\text { Thailand; Vietnam }\end{array}$ \\
\hline $\begin{array}{l}\text { Schima } \\
\text { remotiserrata }\end{array}$ & $\begin{array}{l}\text { Fujian, Guangdong, E Guangxi, S Hunan, Jiangxi of } \\
\text { China }\end{array}$ \\
\hline Schima parviflora & N Guizhou, W Hubei, NW Hunan, E Sichuan of China \\
\hline Schima superba & $\begin{array}{l}\text { Anhui, Fujian, Guangdong, Guangxi, Guizhou, Hainan, } \\
\text { Hubei, Hunan, Jiangxi, Taiwan, Zhejiang of China; } \\
\text { Japan (Ryukyu Islands) }\end{array}$ \\
\hline${ }_{a}^{\text {Schima brevifolia }}$ & Malaysia \\
\hline Schima lobbii ${ }^{a}$ & Malaysia \\
\hline $\begin{array}{l}\text { Schima } \\
\text { monticola }\end{array}$ & Malaysia \\
\hline
\end{tabular}

a: According to The Plant List database (www.theplantlist.org), the species name is unsolved, but it is used by local botanists

\section{Data collection and analysis}

The forests in the study area are subjected to a range of natural and anthropogenic factors such as elevation, topography, natural disturbances and human activities; thus, forests are structurally and floristically heterogeneous and the landscape pattern of vegetation takes the form of mosaic patches. We selected plots in each patch containing Schima species in the study area. During 20152019, we established 71 plots dominated by Schima species in Yunnan (Fig. 3). The plots were established in the locations where it was possible for us to access. The plot size varied between $20 \mathrm{~m} \times 30 \mathrm{~m}$ to $30 \mathrm{~m} \times 40 \mathrm{~m}$ where plot size depended on the size of a patch. Patch size was determined by species composition and topographic similarity.
For the species in each plot, all individuals at least $1.3 \mathrm{~m}$ in height were identified to species level, numbered and tagged, and their diameter at breast height (DBH) and height $(\mathrm{H})$ were recorded. In addition, general information about each plot was noted, such as slope positions, altitude, slope exposure, slope inclination, as well as disturbance histories. Tree stems were classified into four types based on their vertical position, crown position, and height: emergent layer (greater than $28 \mathrm{~m}$ tall), canopy (20-28 $\mathrm{m}$ tall), subcanopy (8-20 $\mathrm{m}$ tall), and shrub layer (1.3-8 $\mathrm{m}$ tall). All understory woody species less than 130 $\mathrm{cm}$ tall, were divided into two classes: (1) $5-50 \mathrm{~cm}$ tall for seedlings and (2) $50-130 \mathrm{~cm}$ for saplings. Within these two classes, each individual was identified, counted, and measured for height and percent cover.

Based on tree sizes, ages of the forest stands, species composition and community structure, as well as degrees of naturalness or disturbance regime of the forests, we judged whether or not the forest stands were in early, middle, or late successional stages.

For all individuals greater than $1.3 \mathrm{~m}$ tall, DBH was used to calculate basal area and then basal area (BA) for each species found in a plot could be determined. In each plot, the relative importance value $[\mathrm{RIV}=$ (Relative density + Relative basal area)/2)] of each species was used to measure the abundance of the species. Plant communities were classified using a floristic similarity dendrogram with Relative $\mathrm{S}$ orensen and Group Average clustering [PCORD software (McCune and Mefford 1999)]. The communities were named according to dominant species. Diversity was calculated for each forest stand using species richness (number of species), the Shannon-Wiener's diversity index (Shannon-Wiener index, $H^{\prime}$; Pielou 1969) and Simpson's diversity index (Simpson index, $D$; Lande 1996). Differences in species richness and diversity indices among habitats were analyzed by the nonparametric Kruskal-Wallis all-pairwise comparisons test, using Analyze-it software (United Kingdom).

Species richness (number of species) and the rarityweighted richness (RWR) (each species is assigned a score-based on the inverse of the number of sites in which a species occurs) (Williams et al. 1996) are used to show the Schima species distribution patterns. A square of $1^{\circ}$ latitude $\times 1^{\circ}$ longitude (a cell per a grid size) was chosen as a geographic unit to show species richness and rarity-weighted richness at present on the map, using ArcGIS v. 10.5. The correlation of species richness and rarity-weighted richness was analyzed using Pearson's correlation coefficient.

\section{Results}

\section{Schima species richness and rarity-weighted richness patterns}

The patterns obtained for species richness and rarityweighted richness (the latter representing concentrations 

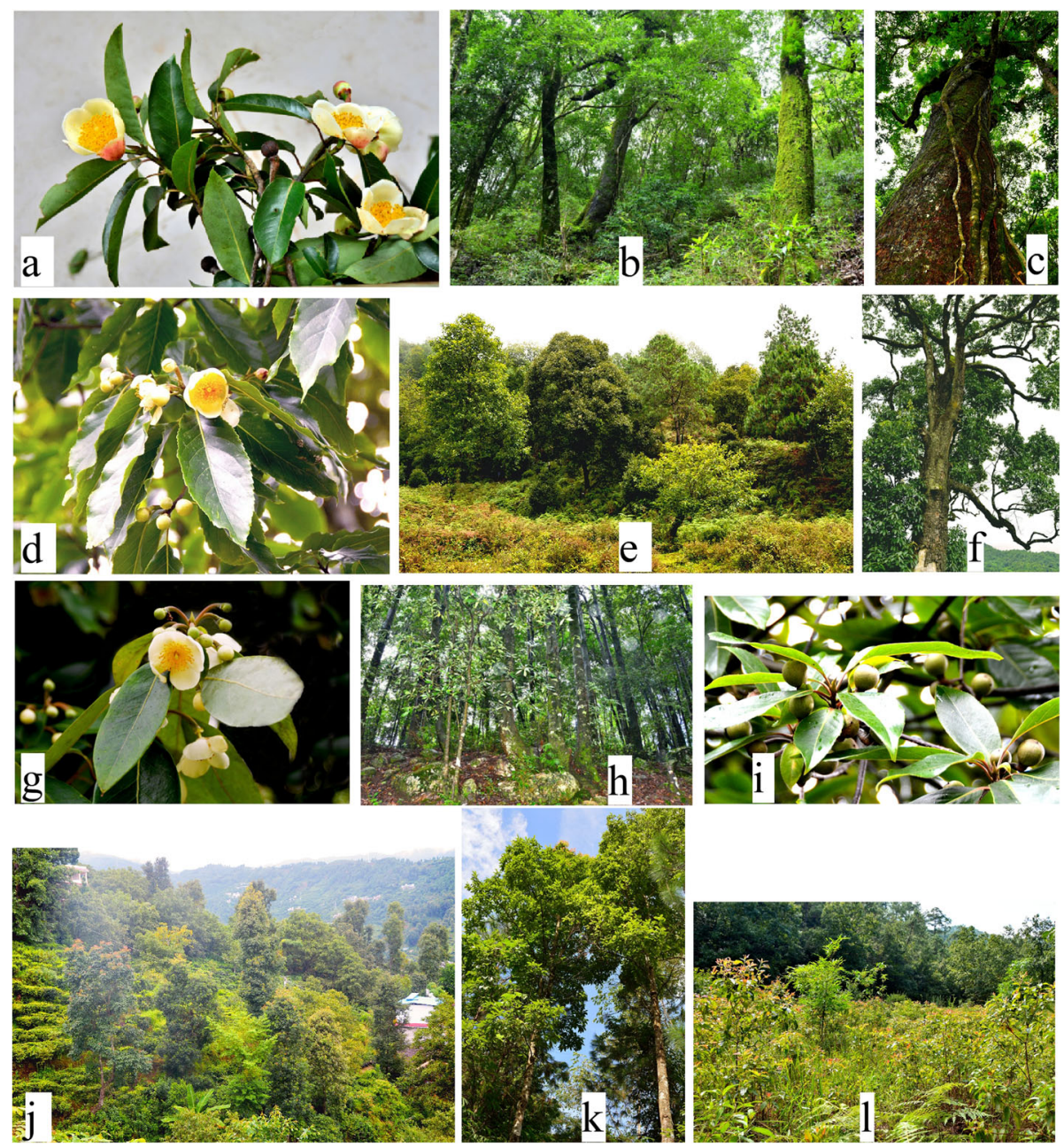

Fig. 2 Representative species, forests and habitats of Schima in Yunnan. a Leaves and flowers of S. noronhae; b A primary forest at late successional stage dominated by S. noronhae and Castanopsis ceratacantha in Wuliangshan, south-central Yunnan; c A tree of S. noronhae with $143 \mathrm{~cm}$ DBH and $40 \mathrm{~m}$ in height; $\mathbf{d}$ Leaves and flowers of S. sericans; e A secondary forest at mid-successional stage dominated by S. sericans, Alnus nepalensis and Pinus yunnanensis in Fengqing, SW Yunnan; $\mathbf{f}$ A mature tree of S. sericans; $\mathbf{g}$ Leaves and flowers of S. argentea; $\mathbf{h}$ A young secondary forest dominated by $S$. argentea in Yongde Daxueshan, SW Yunnan; $\mathbf{i}$ Leaves and fruits of S. khasiana; $\mathbf{j}$ Naturally regenerated S. wallichii trees growing around a farmland; $\mathbf{k}$ S. wallichii trees on the roadsides; I S. wallichii seedlings/saplings in a forest canopy gap in Shuangjing, SW Yunnan

of limited-range species, as well as a high turnover of species between adjacent cells) show that the Schima species are confined to the subtropical and warmtemperate areas of China (Fig. 4a and b). Among 13 species found in China, 8 are distributed in Yunnan (Table 1). The areas of southeastern, south-central, southwestern and western Yunnan show the high species richness (4-7, yellow and red cells in Fig. 4a), while the other regions of China most often have 1-3 species (dark green, blue and light green cells) except for south-central China. The rarity-weighted richness (RWR) greater than 0.2 (yellow and red cells) was found in the areas of northwestern, southeastern, southern and south-central Yunnan, with two sites in Guangxi Province. The outstanding rarity weighted richness in northern Gaoligongshan, NW Yunnan is mostly contributed by Schima sericans which has a very narrow distribution (endemic to NW Yunnan and SE Tibet), and Schima khasiana which is limited to western and southern Yunnan and SE Tibet (Fig. 4b). The distribution patterns of Schima species richness (Fig. 4a) and rarity-weighted richness (Fig. 4b) in the Yunnan area have linear relationships with significant positive correlations (Pearson's $r=0.74$ ).

\section{Forest types, stratification and species diversity Primary forests}

According to the similarity dendrogram, vegetation data of 22 plots in Yunnan were classified into five primary forest types (Fig. 5a): Type PF1, the Schima noronhaeCastanopsis ceratacantha evergreen broad-leaved forest on mountain slopes at elevations $1920-2480 \mathrm{~m}$ in Wuliangshan, south-central Yunnan; Type PF2, the 


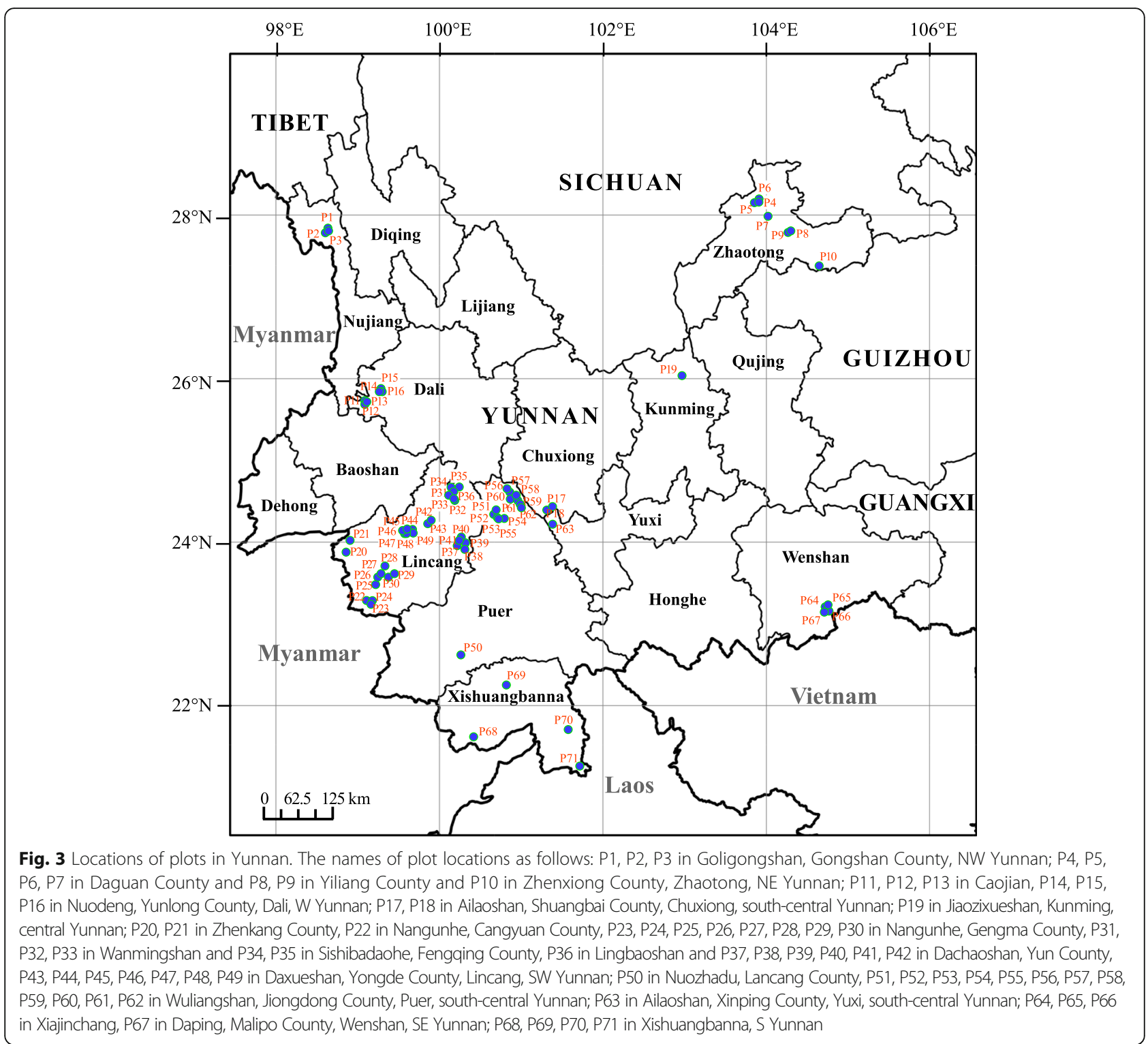

Castanopsis echidnocarpa-Schima khasiana evergreen broad-leaved forest at 2000-2710 m on mountain slopes in Wanmingshan, SW Yunnan; Type PF3, the Tetracentron sinense-Schima villosa deciduous and evergreen broad-leaved mixed forest on steep slopes and stream sides at $2450-2600 \mathrm{~m}$ in Zheonghoushan of the Ailao Mountains, south-central Yunnan; Type PF4, the Castanopsis platyacantha-Schima sinensis evergreen broadleaved forest on mountain slopes at $1800-1950 \mathrm{~m}$ in Daguan, NE Yunnan; Type PF5, Schima wallichii-Castanopsis hystrix evergreen broad-leaved forest in valleys or on mountain slopes at 950-1380 m in Xishuangbanna, S Yunnan. No major anthropogenic disturbances have been found, though some natural disturbances including slight landslides, moderate wind-blow and occasional lightning strike occurred in the forests.
In each forest type, Schima and Castanopsis (S. noronhae and C. ceratacantha in Type PF1, S. khasiana and C. echidnocarpa in Type PF2, S. sinensis and C. platyacantha in Type PF4, S. wallichii and C. hystrix in Type PF5) dominated the canopy (18-28 m), except that Type PF3 was dominated by Tetracentron sinense and S. villosa (Fig. 5b). In Type PF1, PF2, PF3, PF5 forests, Schima also reached emergent layer $(28-36 \mathrm{~m})$. In the subcanopy $(8-18 \mathrm{~m})$, the shrub layer $(3-8 \mathrm{~m})$, and the understory $(<3 \mathrm{~m})$ of the forest Types PF1, PF2, PF4, PF5, Schima was commonly found, while in Type PF3 it was absent in $8-12 \mathrm{~m}$ and infrequent in the shrub layer and the understory.

All the 22 plots of primary forests, taken together, contained 240 woody species, representing 147 genera in 72 families. Each forest type's species composition with 

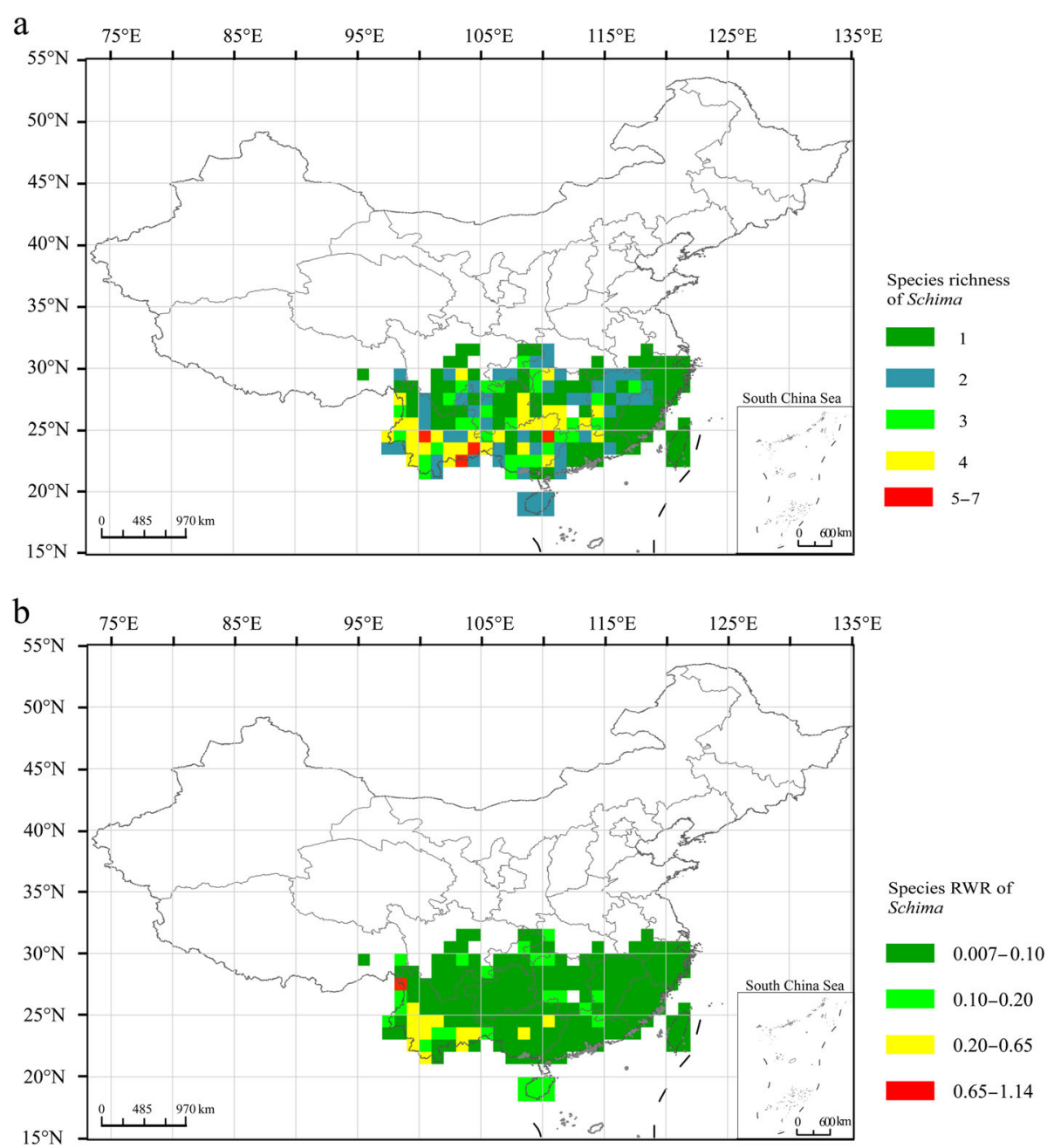

Fig. 4 Species richness and species rarity-weighted richness (RWR) of Schima in Yunnan as compared with those in the other regions of subtropical China. $\mathbf{a}$ Species richness of Schima; $\mathbf{b}$ species rarity-weighted richness (RWR) of Schima

the relative importance value (RIV) is shown in Table 2. Type PF1 was dominated by Schima noronhae and Castanopsis ceratacantha. The other major components were Lithocarpus truncatus, Machilus longipedicellata, Eurya yunnanensis, etc. In the understory, a bamboo species-Yushania polytricha's coverage reached $80 \%$. Type PF2 was co-dominated by Castanopsis echidnocarpa and Schima khasiana along with Lithocarpus xylocarpus, Cyclobalanopsis myrsinifolia, Ternstroemia gymnanthera and Craibiodendron stellatum, etc. Type PF3 was co-dominated by Tetracentron sinense and Schima villosa, and the accompanying species were Illicium simonsii, Ilex triflora, Symplocos sumuntia, etc. Type PF4 was co-dominated by Castanopsis platycantha and Schima sinensis with Acer oliverianum, Lindera thomsonii, Pittosporum tobira, etc. Type PF5 was codominated by Schima wallichii and Castanopsis hystrix. The other components were Castanopsis mekongensis, Lithocarpus truncates, Wendlandia tinctoria and so on.
The Shannon-Wiener diversity index $H^{\prime}$ and the Simpson diversity index $D$ ranged respectively from 2.364 to 3.076, and from 0.864 to 0.931 among the five forest types. The diversity indices were not significantly different among the various forest types (Table 2).

For per hectare basal area, forest Types PF2 and PF1 scored relatively high $\left(111.35,109.33 \mathrm{~m}^{2} \cdot \mathrm{ha}^{-1}\right.$, respectively), followed by Types PF3 $\left(75.25 \mathrm{~m}^{2} \cdot \mathrm{ha}^{-1}\right)$ and PF4 (61.55 $\left.\mathrm{m}^{2} \cdot \mathrm{ha}^{-1}\right)$, and Type PF5 $\left(40.37 \mathrm{~m}^{2} \cdot \mathrm{ha}^{-1}\right)$ (Supplementary Table S1).

\section{Secondary forests}

According to the similarity dendrogram based on vegetation data of 49 plots of secondary forests, there are 6 forest types (Fig. 6a). Type SF1, the Schima argentea secondary evergreen broad-leaved forest was widely found on mountain slopes, in valleys, along roadsides or near farmland at elevations $1920-2650 \mathrm{~m}$ in Yongde daxueshan of SW Yunnan, Dachaoshan of SW Yunnan, 


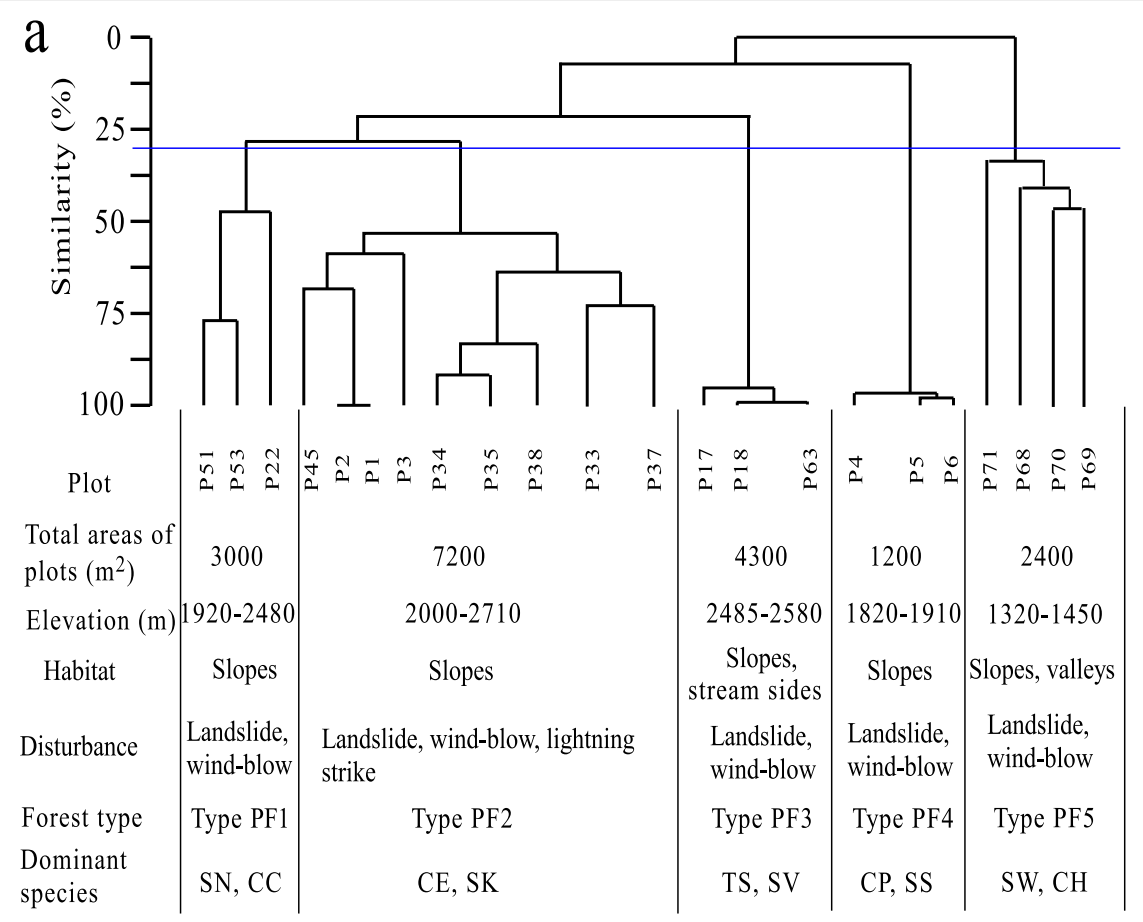

$\mathrm{b}$

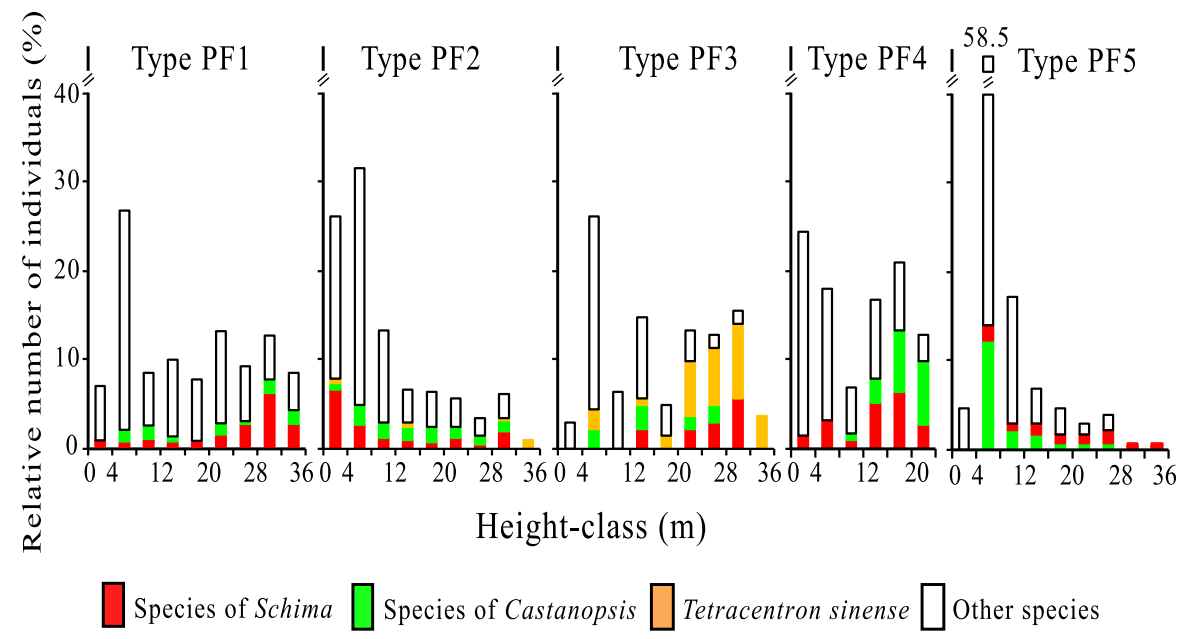

Fig. 5 Floristic dendrogram and stratification of primary forests. a Floristic similarity dendrogram; $\mathbf{b}$ Height-class frequency distribution of species (height $\geq 1.3 \mathrm{~m}$ ). SN = Schima noronhae; CC = Castanopsis ceratacantha; CE = Castanopsis echinocarpa; SK = Schima khasiana; TS = Tetracentron sinense; $\mathrm{SV}=$ Schima villosa; $\mathrm{CP}=$ Castanopsis platyacantha; $\mathrm{SS}=$ Schima sinensis; $\mathrm{SW}=$ Schima wallichii; $\mathrm{CH}=$ Castanopsis hystrix for (a)

Wuliangshan of south-central Yunnan and Jiaozixueshan of central Yunnan; Type SF2, the Schima khasianaDipentodon sinicus secondary evergreen and deciduous broad-leaved mixed forest was found along roadsides or stream sides at $2390-2650 \mathrm{~m}$ in Chaojian, NW Yunnan; Type SF3, the Schima wallichii secondary evergreen broad-leaved forest was commonly found on mountain slopes, in valleys, along roadsides or near farmland at 950-2460 $\mathrm{m}$ in SW, NW and S Yunnan; Type SF4, the Schima sericans-Castanopsis ceratacantha secondary evergreen broad-leaved forest was found on mountain slopes at $2040-2300 \mathrm{~m}$ in Yun County, SW Yunnan; Type SF5, Schima villosa-Rhoiptelea chiliantha secondary evergreen and deciduous broad-leaved mixed forest was found on mountain slopes at $1680-2100 \mathrm{~m}$ in Malipo County, SE Yunnan; Type SF6, the Schima sinensis-Castanopsis platyacantha secondary evergreen broad-leaved forest was found on mountain slopes at 1860-2110 m in Daguan County, Yiliang County and Zhenxiong County of Zhaotong, NE Yunnan. In the 
Table 2 Floristic composition of woody species $(H \geq 1.3 \mathrm{~m})$ for primary forest types containing Schima species as one of the dominants. Only species with relative importance value (RIV) $\geq 1.5 \%$ are shown. The same letter indicates no significant difference $(p>0.05)$ for average number of species and diversity indices among those forest types. SD = Standard deviation. RIV $=$ relative importance value. Dominant species are indicated by boldface

\begin{tabular}{|c|c|c|c|c|c|}
\hline Forest type & Type PF1 & Type PF2 & Type PF3 & Type PF4 & Type PF5 \\
\hline Elevation (m) & $1920-2476$ & $2000-2710$ & $2485-2577$ & 1820-1910 & $900-2100$ \\
\hline \multirow[t]{3}{*}{ Plots } & \multirow[t]{3}{*}{ P51, P53, P22 } & $\mathrm{P} 45, \mathrm{P} 2, \mathrm{P} 1, \mathrm{P3}$ & \multirow[t]{3}{*}{ P17, P18, P63 } & \multirow[t]{3}{*}{ P4, P5, P6 } & P71, P68, \\
\hline & & P34, P35, P38, & & & P70, P69 \\
\hline & & P33, P37 & & & \\
\hline Number of plots & 3 & 9 & 3 & 3 & 4 \\
\hline Total areas of plots $\left(\mathrm{m}^{2}\right)$ & 3000 & 7200 & 4300 & 1200 & 2400 \\
\hline Total number of species & 85 & 85 & 30 & 39 & 48 \\
\hline Average number of species & $32 \pm 10.07^{\mathrm{a}}$ & $17 \pm 5.84^{\mathrm{a}}$ & $15 \pm 6.51^{a}$ & $18 \pm 3.46^{\mathrm{a}}$ & $32 \pm 14.08^{\mathrm{a}}$ \\
\hline Shannon-Wiener $H^{\prime} \pm S D$ & $3.076 \pm 0.44^{\mathrm{a}}$ & $2.364 \pm 0.50^{\mathrm{a}}$ & $2.392 \pm 0.50^{\mathrm{a}}$ & $2.506 \pm 0.14^{\mathrm{a}}$ & $2.477 \pm 0.49^{\circ}$ \\
\hline Simpson $D \pm S D$ & $0.931 \pm 0.04^{\mathrm{a}}$ & $0.864 \pm 0.09^{a}$ & $0.87 \pm 0.06^{\mathrm{a}}$ & $0.891 \pm 0.01^{\mathrm{a}}$ & $0.869 \pm 0.05^{c}$ \\
\hline Species & RIV (\%) & RIV (\%) & RIV (\%) & RIV (\%) & RIV (\%) \\
\hline
\end{tabular}

Evergreen broad-leaved

Schima noronhae

Castanopsis ceratacantha

Lithocarpus truncatus

Eurya yunnanensis

Phoebe puwenensis

Lithocarpus grandifolius

Machilus duthiei

Lindera supracostata

Lithocarpus hancei

Manglietia insignis

Michelia baillonii

Cinnamomum bejolghota

Castanopsis echinocarpa

Schima khasiana

Lithocarpus xylocarpus

Cyclobalanopsis myrsinifolia

Lithocarpus mairei

Cyclobalanopsis lamellosa

Myrsine semiserrata

Cinnamomum iners

Schima argentea

Rhododendron sp.

schima villosa

Castanopsis wattii

Illicium simonsii

Ilex triflora

Symplocos sumuntia

Machilus salicina

Castanopsis platyacantha

Schima sinensis

\subsection{2}

10.00

7.12

3.68

3.14

3.01

2.99

2.61

2.15

2.00

1.97

1.91

$-$

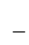

$-$

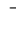

$-$

$-$

$-$

$-$

$-$

$-$

$-$

$-$

$-$

$-$

$-$

$-$

$-$

$-$

$-$

$-$
4.02
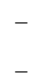

$-$

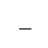

3.53

4.80

1.65

$-$

14.23

10.97

6.40

5.36

3.89

2.75

1.83

1.83

1.77

1.55
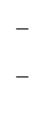

-

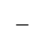

$-$

$-$

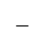

$-$
20.80

5.79

2.90

2.82

1.78

1.77

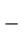


Table 2 Floristic composition of woody species $(H \geq 1.3 \mathrm{~m})$ for primary forest types containing Schima species as one of the dominants. Only species with relative importance value (RIV) $\geq 1.5 \%$ are shown. The same letter indicates no significant difference $(p>0.05)$ for average number of species and diversity indices among those forest types. SD = Standard deviation. RIV $=$ relative importance value. Dominant species are indicated by boldface (Continued)

\begin{tabular}{|c|c|c|c|c|c|}
\hline Forest type & Type PF1 & Type PF2 & Type PF3 & Type PF4 & Type PF5 \\
\hline Lindera thomsonii & - & - & - & 5.92 & - \\
\hline Symplocos anomala & - & - & - & 3.44 & - \\
\hline Ilex subodorata & - & - & - & 2.77 & - \\
\hline Pittosporum perryanum & - & - & - & 2.75 & - \\
\hline Micheliacaloptila & - & - & - & 2.08 & - \\
\hline Vaccinium mandarinorum & - & - & - & 1.74 & - \\
\hline Schima wallichii & - & - & - & - & 16.74 \\
\hline Castanopsis hystrix & - & - & - & - & 16.44 \\
\hline Castanopsis mekongensis & - & - & - & - & 8.71 \\
\hline Wendlandia tinctoria & - & - & - & - & 4.48 \\
\hline Machilus rufipes & - & - & - & - & 3.35 \\
\hline Anneslea fragrans & - & - & - & - & 3.25 \\
\hline Syzygium cumini & - & - & - & - & 3.08 \\
\hline Pertusadina metcalfii & - & - & - & - & 2.69 \\
\hline Castanopsis calathiformis & - & - & - & - & 2.12 \\
\hline Vaccinium bracteatum & - & - & - & - & 2.04 \\
\hline Machilus tenuipilis & - & - & - & - & 1.74 \\
\hline Litsea martabanica & - & - & - & - & 1.70 \\
\hline Ilex godajam & - & - & - & - & 1.60 \\
\hline Phoebe lanceolata & - & - & - & - & 1.54 \\
\hline \multicolumn{6}{|l|}{ Deciduous broad-leaved } \\
\hline Betula alnoides & 1.55 & - & - & - & - \\
\hline Tetracentron sinense & - & - & 34.88 & - & - \\
\hline Acer amplum & - & - & 1.67 & - & - \\
\hline Acer oliverianum & - & - & - & 3.96 & - \\
\hline Cornus controversa & - & - & - & 1.77 & - \\
\hline Cerasus patentipila & - & - & - & 1.69 & - \\
\hline \multicolumn{6}{|l|}{ Coniferous } \\
\hline Tsuga dumosa & - & 3.19 & - & - & \\
\hline Taxus wallichiana var. chinensis & - & - & 2.99 & - & - \\
\hline
\end{tabular}

secondary forests, there were evidences of anthropogenic disturbances such as occasional cattle and goats browsing or selective firewood cutting or collecting litters on the forest floor. Besides the moderate human activities, natural disturbances including landslides, wind-blow, and lightning strikes also occurred there. Especially in forest Types SF1 and SF3, there were many different types of disturbances.

In each secondary forest type, Schima species generally dominated the canopy $(18-28 \mathrm{~m})$ (Fig. 6b). In Type SF1, SF3, SF5 forests, S. argentea, S. wallichii and $S$. villosa reached the emergent layer $(28-36 \mathrm{~m})$. In the subcanopy $(8-18 \mathrm{~m})$, the shrub layer $(3-8 \mathrm{~m})$, and the understory $(<3 \mathrm{~m})$ of Types SF1, SF2, SF3, SF5, Schima was commonly found, while only few trees of $S$. sericans were in $8-28 \mathrm{~m}$ in Type SF4, $S$. sinensis was absent in $1.3-4 \mathrm{~m}$ in Type SF6. Except Type SF2, all the secondary forests had species of Castanopsis as a major component.

All the 49 plots of secondary forests, taken together, contained 370 woody species, representing 169 genera in 68 families. Species composition of each forest type with the relative importance value (RIV) is shown in Table 3. Type SF1, the Schima argentea secondary forest was dominated only by $S$. argentea. The other components were Castanopsis orthacantha, Castanopsis echinocarpa 

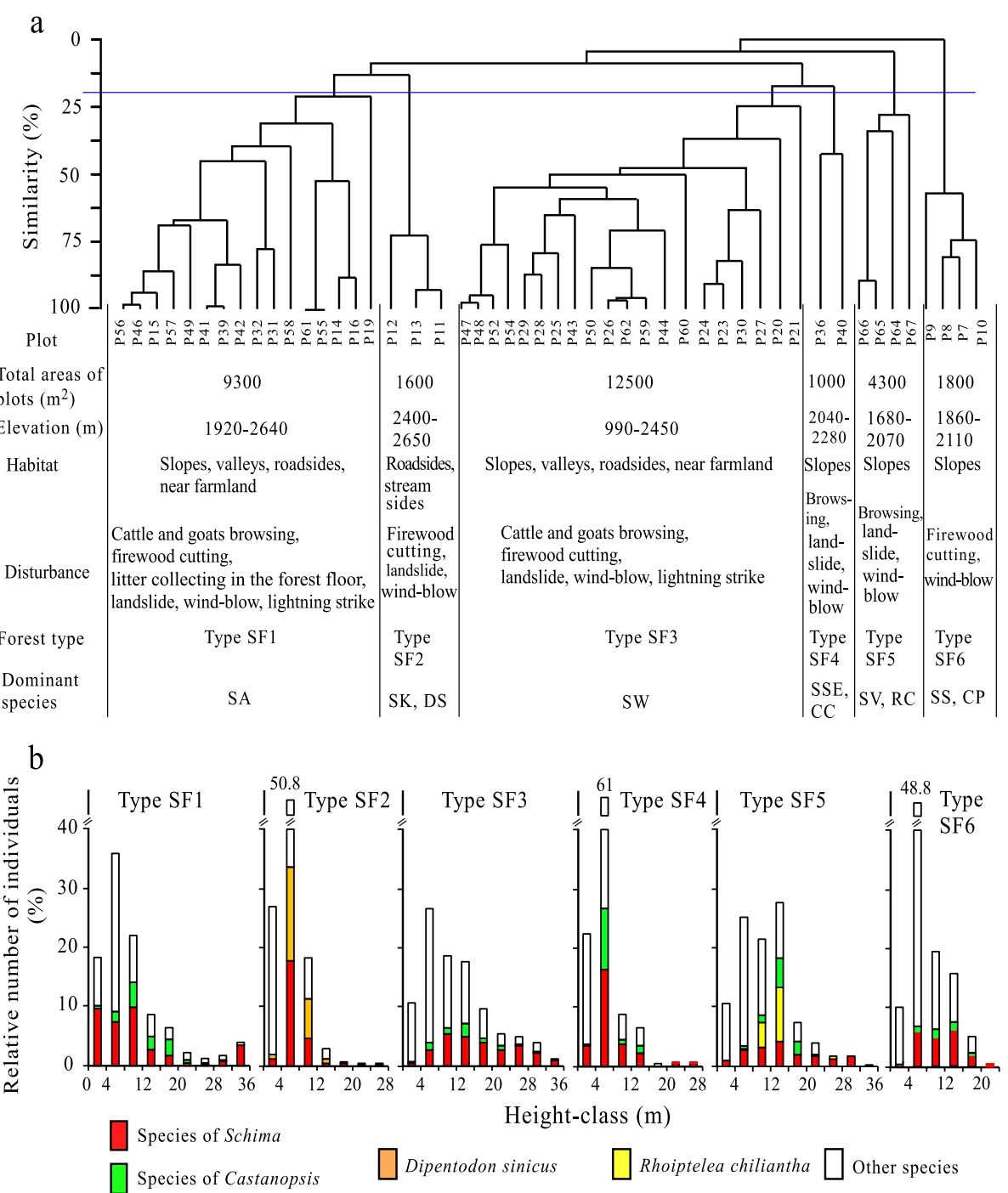

Fig. 6 Floristic dendrogram and stratification of secondary forests. a Floristic similarity dendrogram; b Height-class frequency distribution of species (height $\geq 1.3 \mathrm{~m}$ ). SA = Schima argentea; SK = Schima khasiana; DS = Dipentodon sinicus; SW = Schima wallichii; SSE = Schima sericans; CC = Castanopsis ceratacantha; SV = Schima villosa; RC = Rhoiptelea chiliantha; SS = Schima sinensis; $\mathrm{CP}=$ Castanopsis platyacantha for (a)

and Rhododendron delavayi, etc. Type SF2, the Schima khasiana-Dipentodon sinicus secondary forest was codominated by S. khasiana and Dipentodon sinicus. The other components were Illicium simonsii, Cyclobalanopsis augustinii and so on. In the understory, many Hypericum monogynum invaded. Type SF3, the Schima wallichii secondary was dominated only by $S$. wallichii, and its components were Castanopsis calathiformis, Lithocarpus xylocarpus, Betula alnoides, Alnus nepalensis, Pinus yunnanensis, etc. Type SF4, the Schima sericans-Castanopsis ceratacantha secondary forest, was codominated by $S$. sericans and $C$. ceratacantha, along with other components including Schima wallichii, Lyonia doyonensis, Ilex polyneura, Eurya nitida, Anneslea fragrans, Rhododendron vialii, etc. Type SF5, Schima
villosa-Rhoiptelea chiliantha secondary forest was codominated by $S$. villosa and deciduous $R$. chiliantha. The companion species were Castanopsis ceratacantha, Lithocarpus truncates, Eurya impressinervis, Craibiodendron stellatum, ect. Type SF6, the Schima sinensisCastanopsis platyacantha secondary forest was codominated by $S$. sinensis and $C$. platyacantha along with Lithocarpus hancei, Camellia pitardii, Symplocos anomala and so on. In the secondary forests, there were more pioneer deciduous broad-leaved species such as Alnus nepalensis, Betula alnoides and coniferous Pinus yunnanensis compared to the primary forests.

Among the 6 secondary forest Types SF1-SF6, the Shannon-Wiener diversity $H^{\prime}$ and the Simpson diversity $D$ respectively ranged from 2.109 to 2.429 and $0.793-$ 
Table 3 Floristic composition of woody species (Height $\geq 1.3 \mathrm{~m}$ ) for secondary forest types containing Schima species as one of the dominants. Only species with relative importance values (RIV) $\geq 1.5 \%$ are shown. The same letter indicates no significant difference $(p>0.05)$ for average number of species and diversity indices among those forest types. SD = Standard deviation. RIV = relative importance value. Dominant species are indicated by boldface

\begin{tabular}{|c|c|c|c|c|c|c|}
\hline Forest type & Type SF1 & Type SF2 & Type SF3 & Type SF4 & Type SF5 & Type SF6 \\
\hline Elevation (m) & $1923-2640$ & $2398-2636$ & $990-2451$ & $2043-2280$ & $1680-2066$ & $1860-2110$ \\
\hline \multirow[t]{7}{*}{ Plots } & P56, P46, P15, & P12, P13, & P47, P48, P52, & P36, P40 & P66, P65, & P9, P8, P7, \\
\hline & P57, P49, P41, & P11 & P54, P29, P28, & & P64, P67 & P10 \\
\hline & P39, P42, P32, & & P25, P43, P50, & & & \\
\hline & P31, P58, P61, & & P26, P62, P59, & & & \\
\hline & P65, P14, P16, & & P44, P60, P24, & & & \\
\hline & P19 & & P23, P30, P27, & & & \\
\hline & & & P20, P21 & & & \\
\hline Number of plots & 16 & 3 & 20 & 2 & 4 & 4 \\
\hline Total areas of plots $\left(\mathrm{m}^{2}\right)$ & 9300 & 1600 & 12,500 & 1000 & 4300 & 1800 \\
\hline Total number of species & 122 & 49 & 189 & 35 & 47 & 53 \\
\hline Average number of species & $17 \pm 4.50^{\mathrm{a}}$ & $26 \pm 1.53^{\mathrm{a}}$ & $16 \pm 4.91^{\mathrm{a}}$ & $23 \pm 8.50^{\mathrm{a}}$ & $17 \pm 5.94^{\mathrm{a}}$ & $17 \pm 4.79^{a}$ \\
\hline Shannon-Wiener $H^{\prime} \pm S D$ & $2.109 \pm 0.38^{\mathrm{a}}$ & $2.31 \pm 0.29^{\mathrm{a}}$ & $2.284 \pm 0.37^{\mathrm{a}}$ & $2.429 \pm 0.37^{\mathrm{a}}$ & $2.173 \pm 0.49^{\mathrm{a}}$ & $2.289 \pm 0.3^{\mathrm{a}}$ \\
\hline Simpson $D \pm S D$ & $0.793 \pm 0.11^{\mathrm{a}}$ & $0.833 \pm 0.05^{\mathrm{a}}$ & $0.95 \pm 0.07^{\mathrm{a}}$ & $0.909 \pm 0^{\mathrm{a}}$ & $0.801 \pm 0.13^{\mathrm{a}}$ & $0.846 \pm 0.05^{\mathrm{a}}$ \\
\hline Importance value & RIV (\%) & RIV (\%) & RIV (\%) & RIV (\%) & RIV (\%) & RIV (\%) \\
\hline
\end{tabular}

Species

\section{Evergreen broad-leaved}

Schima argentea
Castanopsis orthacantha
Castanopsis echinocarpa
Myrica esculenta
Rhododendron delavayi
Lyonia ovalifolia
Schima khasiana
Lyonia ovalifolia var. lanceolata
Hypericum monogynum
Illicium simonsii
Vaccinium mandarinorum
Cyclobalanopsis augustinii
Lithocarpus confinis
Eurya nitida
Schima wallichii
Castanopsis calathiformis
Lithocarpus xylocarpus
Lithocarpus fenestratus
Litsea martabanica
Schima sericans
Castanopsis ceratacantha
Rhododendron vialii
Anneslea fragrans
Mangliecarpus mianningensis

$\begin{array}{ll}- & 7.9\end{array}$

- 66

$\begin{array}{ll}- & 5.0\end{array}$

$\begin{array}{ll}- & 3.8 \\ -\end{array}$

$\begin{array}{ll}- & 3.7 \\ -\end{array}$

- 18

-

-


Table 3 Floristic composition of woody species (Height $\geq 1.3 \mathrm{~m}$ ) for secondary forest types containing Schima species as one of the dominants. Only species with relative importance values (RIV) $\geq 1.5 \%$ are shown. The same letter indicates no significant difference $(p>0.05)$ for average number of species and diversity indices among those forest types. SD = Standard deviation. RIV $=$ relative importance value. Dominant species are indicated by boldface (Continued)

\begin{tabular}{|c|c|c|c|c|c|c|}
\hline Forest type & Type SF1 & Type SF2 & Type SF3 & Type SF4 & Type SF5 & Type SF6 \\
\hline Craibiodendron stellatum & - & - & - & 2.6 & - & - \\
\hline Schima villosa & - & - & - & - & 22.4 & - \\
\hline Castanopsis remotidenticulata & - & - & - & - & 12.9 & - \\
\hline Lithocarpus truncatus & - & - & - & - & 7.0 & - \\
\hline Eurya impressinervis & - & - & - & - & 6.0 & - \\
\hline Lithocarpus megalophyllus & - & - & - & - & 2.1 & 2.5 \\
\hline Elaeocarpus decipiens & - & - & - & - & 1.7 & - \\
\hline Reevesia pubescens & - & - & - & - & 1.5 & - \\
\hline Schima sinensis & - & - & - & - & - & 23.5 \\
\hline Castanopsis platyacantha & - & - & - & - & - & 15.9 \\
\hline Camellia pitardii & - & - & - & - & - & 6.2 \\
\hline Lithocarpus hancei & - & - & - & - & - & 5.1 \\
\hline Symplocos anomala & - & - & - & - & - & 4.3 \\
\hline Symplocos lucida & - & - & - & - & - & 4.3 \\
\hline Tetradium ruticarpum & - & - & - & - & - & 3.9 \\
\hline Rhododendron coeloneurum & - & - & - & - & - & 2.6 \\
\hline Rhododendron calostrotum & - & - & - & - & - & 2.0 \\
\hline \multicolumn{7}{|l|}{ Deciduous broad-leaved } \\
\hline Lyonia doyonensis & 3.2 & - & & 8.6 & - & - \\
\hline Alnus nepalensis & 2.5 & - & 3.1 & & 2.0 & - \\
\hline Ilex polyneura & 1.9 & - & - & 8.3 & - & - \\
\hline Dipentodon sinicus & - & 20.2 & - & - & - & 2.7 \\
\hline Sorbus folgneri & - & 2.8 & - & - & - & - \\
\hline Padus brachypoda & - & 2.3 & - & - & - & - \\
\hline Tetracentron sinense & - & 1.9 & - & - & - & - \\
\hline Lindera obtusiloba & - & 1.7 & - & - & - & - \\
\hline Litsea pungens & - & 1.7 & - & - & - & - \\
\hline Salix matsudana & - & 1.5 & - & - & - & - \\
\hline Betula alnoides & - & - & 4.4 & - & - & - \\
\hline Rhoiptelea chiliantha & - & - & - & - & 17.4 & - \\
\hline Quercus acutissima & - & - & - & - & 2.4 & - \\
\hline Acer sterculiaceum & - & - & - & - & - & 2.2 \\
\hline Rehderodendron macrocarpum & - & - & - & - & - & 2.1 \\
\hline Enkianthus chinensis & - & - & - & - & - & 1.9 \\
\hline Coniferous & - & - & - & - & - & - \\
\hline Pinus yunnanensis & 3.7 & - & - & - & - & - \\
\hline Tsuga dumosa & - & 2.5 & - & - & - & - \\
\hline
\end{tabular}

0.950. No significant difference among the diversity indices were found in all the secondary forest types. However, the Shannon-Wiener indices of the secondary forests were significantly lower than those of the primary forests $(p \leq 0.05)$ (Table 3$)$.
For per hectare basal area, all the six secondary forest Types SF1-SF6 scored relatively low (23.23-45.95 $\mathrm{m}^{2} \cdot \mathrm{ha}^{-1}$, Supplementary Table S2). It is clear that the basal area per hectare of the secondary forests is much lower than that of the primary forests. 
Along latitudinal, longitudinal and elevational gradients, the distribution pattern of forests containing Schima species as one of dominants in Yunnan is shown in Fig. 7. For both the primary forests and the secondary forests as a whole, Schima species were found at elevations between 990 and $2600 \mathrm{~m}$. S. noronhae as a top dominant was only found in primary forests in Wuliangshan, while S. wallichii appeared in both primary and secondary forests in Xishuangbanna, Nangunhe and Yongde daxueshan. S. khasiana in Gaoligongshan, Schima villosa in Ailaoshan and Malipo, S. sinensis in Daguan as a second or third dominant appeared in primary forests. However, the four species, i.e. S. wallichii, S. khasiana, Schima villosa, and S. sinensis, were more often seen as a top dominant found in secondary forests, and $S$. argentea and S. sericans were only found as a top dominant in secondary forests.

\section{Regeneration dynamics}

The DBH-class frequency distribution of species can reveal their population structure and regeneration dynamics. In the primary forests, the DBH-class frequency distribution of each of the five Schima species i.e. S. noronhae, S. khasiana, S. wallichii, Schima villosa, S. sinensis shows a sporadic type with several peaks, indicating that recruitments varied by chance with the regeneration mainly depending on disturbances (e.g. canopy gap regeneration) (Fig. 8). S. noronhae had peaks at $25-30$ and $45-50 \mathrm{~cm} \mathrm{DBH}$, with very few individuals less than 25 $\mathrm{cm}$ DBH. Some $S$. noronhae trees larger than $80 \mathrm{~cm}$ DBH were found, and its maximum DBH reached 145 cm (maybe ca. 280 years old based on our limited data of core samples). S. khasiana had a discontinued distribution between 5 and $155 \mathrm{~cm} \mathrm{DBH}$, and more individuals smaller than $10 \mathrm{~cm}$ DBH were found. S. wallichii had relatively more trees in $30-35$ and $5-10 \mathrm{~cm} \mathrm{DBH}$, and reached $135 \mathrm{~cm}$ DBH (maybe ca. 152 years old based on our limited data of core samples) but was absent in 40-45, 55-60, 80-100, 105-130 cm DBH. Schima villosa only had 2 trees in the DBH-classes less than $50 \mathrm{~cm}$, then it discontinuously distributed in $55-105 \mathrm{~cm}$ DBH. Schima sinensis had more trees in $10-25 \mathrm{~cm}$ DBH and reached $70 \mathrm{~cm} \mathrm{DBH}$, but was completely absent between 35 and $69 \mathrm{~cm} \mathrm{DBH}$. For all the Schima species except $S$. khasiana, it evidently shows the great lack of young trees and poor regeneration. The DBH-class frequency distribution of the major species of each primary forest type is provided in Supplementary Table S1.

In the secondary forests, the DBH-class frequency distribution of each of the six Schima species, i.e. S. argentea, S. khasiana, S. wallichii, S. villosa, S. sinensis and S. sericans also generally shows a sporadic type with multipeaks, indicating that recruitments varied by chance with the regeneration depending on disturbances (e.g. canopy gap regeneration) (Fig. 8). Since moderate human activities or moderate natural disturbances in the secondary forests (Fig. 6a), many forest gaps formed, so abundant individuals of $S$. argentea, S. khasiana, S. wallichii in DBH-classes smaller than $30 \mathrm{~cm}$, and overwhelmingly more young trees in $0-10 \mathrm{~cm} \mathrm{DBH} \mathrm{(Fig.} \mathrm{8).} \mathrm{S.} \mathrm{argentea}$ and $S$. wallichii respectively reached $75 \mathrm{~cm} \mathrm{DBH}$, while S. khasiana, S. villosa, S. sinensis and S. sericans reached $55 \mathrm{~cm} \mathrm{DBH}$, respectively. The DBH-class frequency distribution of the major species of each secondary forest type is provided in Supplementary Table S2. Many small trees of non-Schima canopy species were also found in the secondary forests.

Seedlings/saplings of these seven Schima species were mainly found in well-lit sites including canopy gaps, forest edges and roadsides (Fig. 9). Canopy gaps contributed the most to the establishment of seedlings/saplings. However, S. noronhae, S. khasiana and S. wallichii had some established seedlings/saplings under canopies. The dense coverage (80\%) of Yushania polytricha of bamboo in the understory of the forest Type PF1 impeded the regeneration of $S$. noronhae. Notably, abundant seedlings/ saplings of $S$. wallichii and S. argentea were found, while the numbers of seedlings/sapling of S. sinensis, S. villosa, S. sericans were rather limited (Fig. 9). Since there were more canopy gaps in the secondary forests than the primary forests, the regeneration of these Schima species in the secondary forests had much better recruitments than those in the primary forests.

\section{Discussion}

\section{Forest characteristics}

Our study demonstrates that Schima is often codominated with or associated with various species of Castanopsis (e.g. Castanopsis ceratacantha, C. echinocarpa, C. platyacantha and $C$. hystrix) in the evergreen broadleaved forests of Yunnan. In fact, it is also true in other regions of China and East Asia, as exemplified by Schima superba associated with Castanopsis carlesii in Tiantong, Zhejiang (Da et al. 2004; Yang et al. 2006; Song 2007), associated with Castanopsis eyrei in Gutianshan, Zhejiang (Zhu et al. 2008) and Wuyishan, Jiangxi (Cai and Song 1997), associated with Castanopsis chinensis on Mt. Dinghu, Guangdong (Huang et al. 2000), associated with Castanopsis fabri and Castanopsis fargesii in Wanmulin, Fujian (Huang et al. 1997), associated with Castanopsis cuspidata var. carlesii in Taiwan (Tang et al. 2013). Schima argentea associated with Castanopsis carlesii var. spinulosa in Jinyunshan, Chongqing (Zeng et al. 2010). Schima sinensis associated with Castanopsis platyacantha on Mt. Emei, Sichuan (Yang et al. 1994; Tang et al. 2007). $S$. wallichii associated with Castanopsis sieboldii in Okinawa, southwestern Japan (Xu et al. 2008). S. wallichii associated with Castanopsis tribuloides in Bhutan 


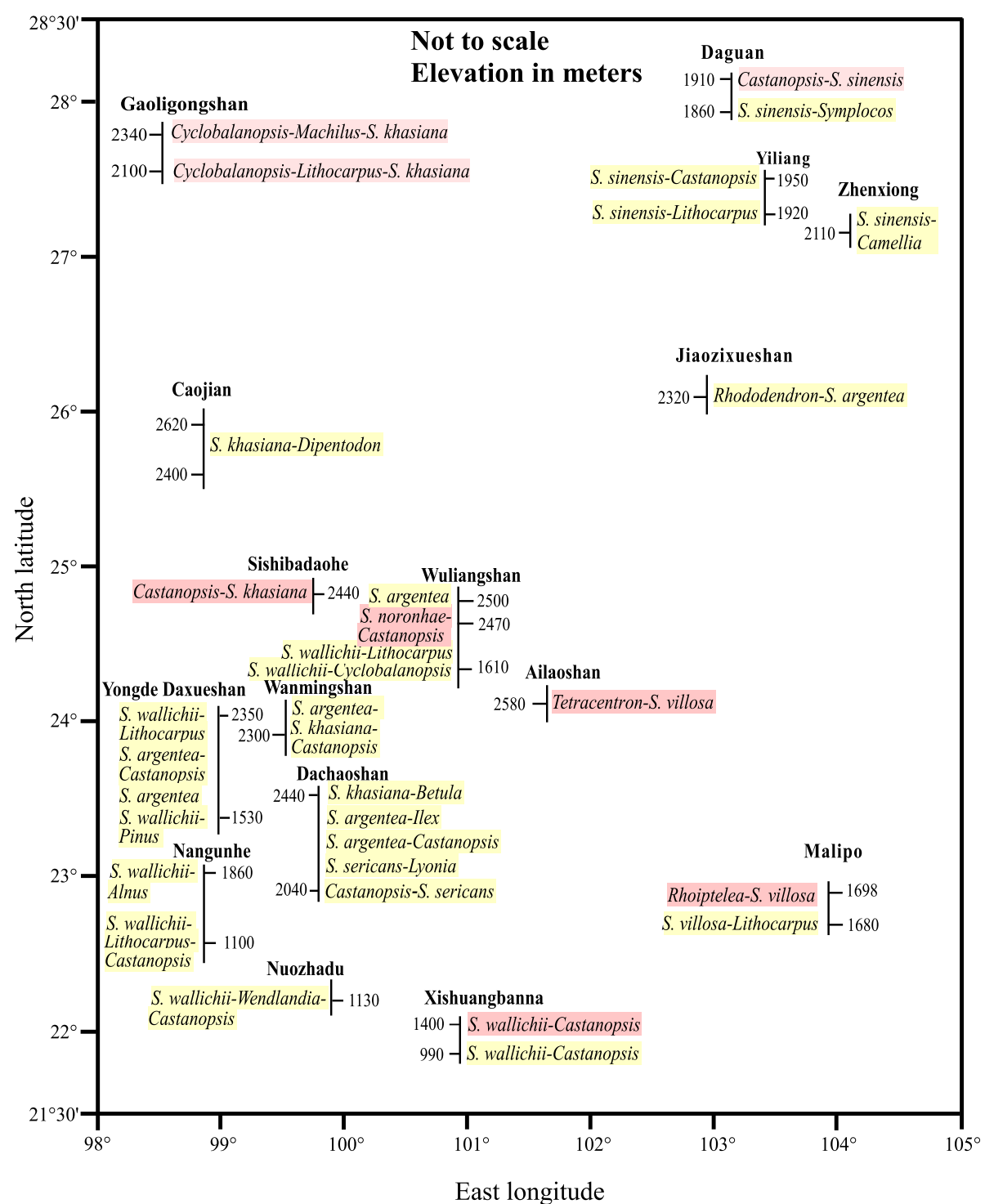

Fig. 7 The spatial distribution pattern of representative forest stands containing Schima species as one of the dominants in Yunnan. The communities red highlighted indicate primary forest stands. The communities yellow highlighted indicate secondary forest stands. Species names are given only for species of Schima. For other taxa, only genera are listed. S. = Schima

Himalaya (Wangda and Ohsawa 2006), associated with Castanopsis indica in eastern Nepal Himalaya (Ohsawa 1986), and associated with Castanopsis lanceifolia in Meghalaya, NE India (Tripathi and Shankar 2014).

The Shannon-Wiener index $H^{\prime}$ of our studied primary forests and secondary forests is $2.563 \pm 0.48$ (average \pm SD) and $2.232 \pm 0.36$, respectively. The indices of the forests in Yunnan are higher than those (1.768 for Dongbeishan, 1.566 for Fuzhou) of the Schima superba-Pinus massoniana forest in Dongbeishan, Zhejiang (Wang et al. 2015) and in the National Forest Park of Fuzhou, Fujian (Cheng 2006), and higher than those (1.255-1.886) of Castanopsis platyacantha-Schima sinensis forest in Wawushan, Sichuan (Bao et al. 2000), also higher than that (1.72) of Schima superba-Castanopsis sclerophylla forest and that $(2.19 \pm 0.46)$ of Schima superba forest in Tiangtong, Zhejiang (He et al. 1998), while the indices in Yunnan are lower than that (2.76) of Schima superbaCastanopsis carlesii in Tiantong (He et al. 1998), Zhejiang and that (3.150) of Castanopsis chinensis-Schima superba in Dingfoshan, Guangdong (Huang et al. 2000). This is probably related to the different degrees of naturalness of the forests in the various study sites.

\section{Ecological traits}

The seven Schima species grow in a warm or mild climate with ample moisture and humidity in the study area. They mainly regenerate in canopy gaps formed 


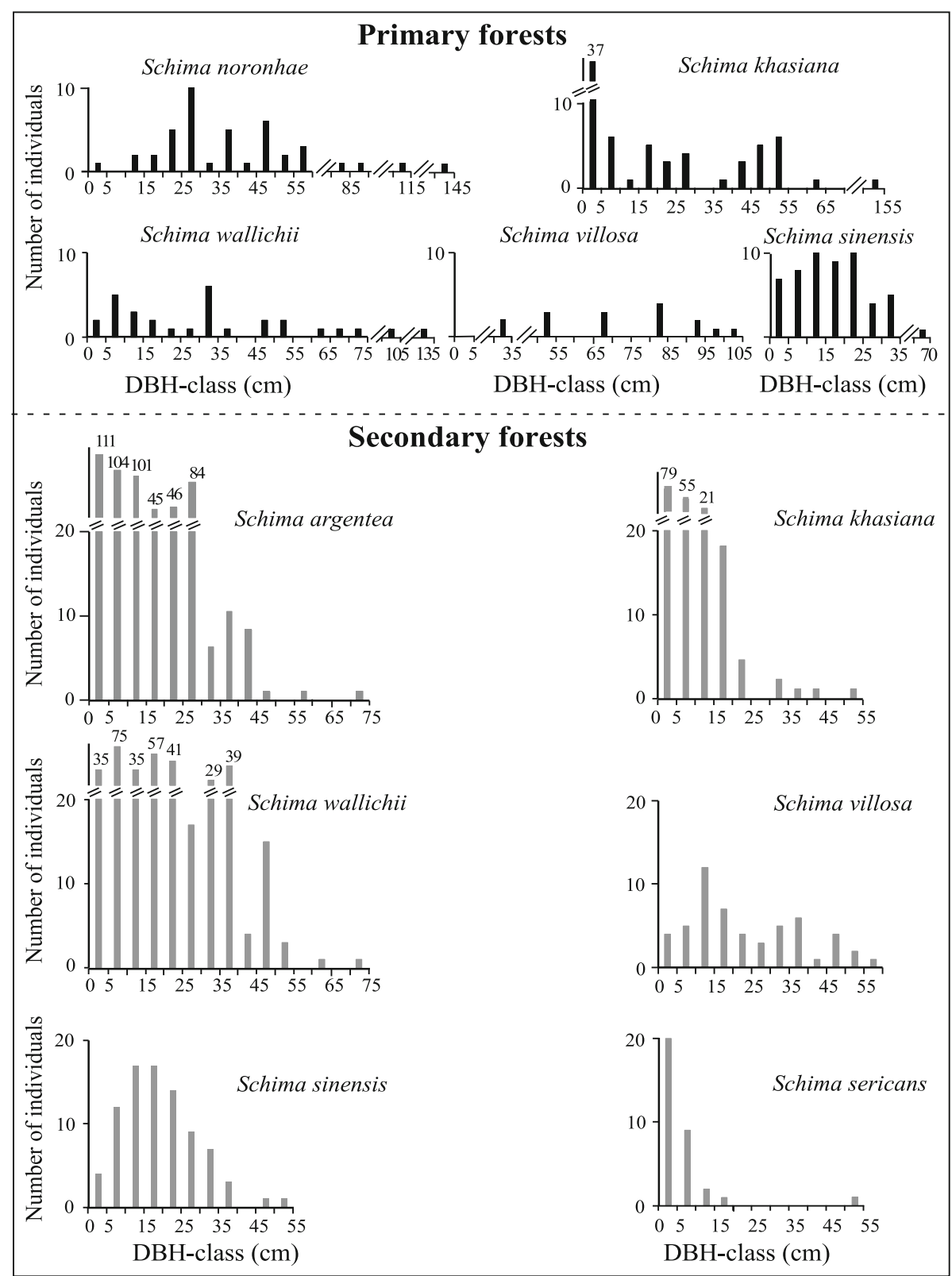

Fig. $8 \mathrm{DBH}$-class frequency distribution of Schima species in primary and secondary forests

under an existing gap disturbance regime (moderate anthropogenic and natural disturbances). Many of Schima species are shade-intolerant, and they more commonly dominate the early or middle successional forests (secondary forests). The long life-span of Schima species assures their presence in late successional forests (primary forests), and even co-dominate the canopy layer along with dominants of different genera. However, three species, i.e. S. noronhae, S. khasiana, S. wallichii are bimodal type species having shade-intolerant and somehow shade-tolerant traits since their seedlings/saplings were found in both well-lit and shady micro-sites. Schima species with winged seeds widely disperse by wind. After their regeneration is established, they will form a mosaic of forest stand structure across the landscape in the subtropical zone of Yunnan. The seven Schima species survive best in moderately disturbed sites. Much less seedlings/saplings of the three species i.e. S. sinensis, S. villosa and S. sericans were found than the other four species $(S$. wallichii, S. argentea, S. noronhae, S. khasiana), because the three species are found only in a few forest patches in Yunnan. 


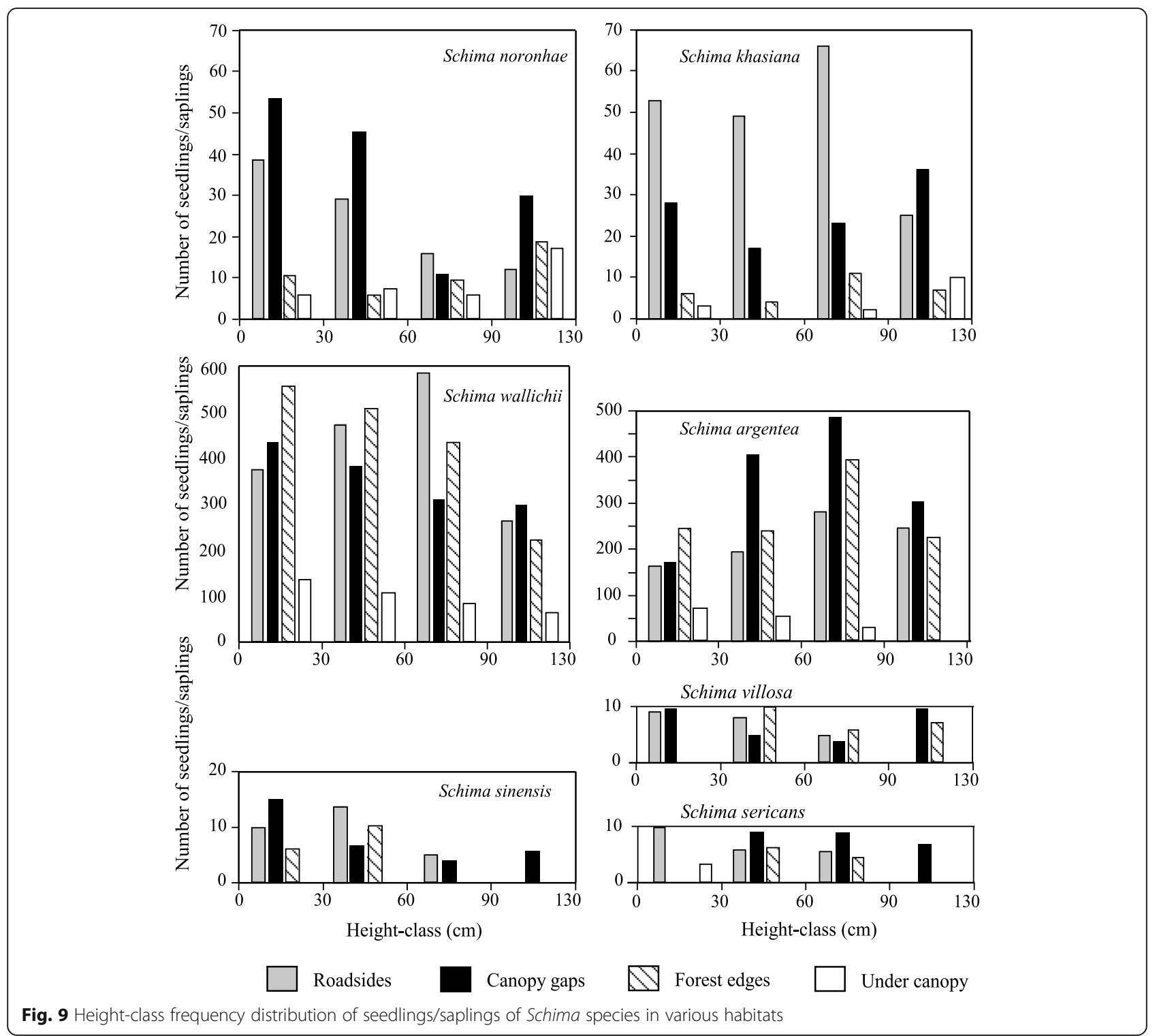

The Schima species under this study, ecological traits are similar to those of Schima superba in eastern China, which is a fast-growing tree with a higher growth rate during its youth (Wei 2017) and has a growth plasticity and a certain shade-tolerance, meanwhile forest canopy gaps support its seed germination and seedling/sapling establishment (Song 2007). The S. superba forest in Guangxi is an earlier type of recovering evergreen broad-leaved forest resulting from serial communities following destruction of original evergreen broadleaved forest through progressive succession. It will be replaced by Castanopsis species (Wang and Li 1999). In our study area of Yunnan, S. noronhae is found in the primary forests at the late successional stage as the top dominant, and either S. khasiana, S. wallichii, S. villosa or S. sinensis presents as one of the dominants in both late successional forests and early or middle-seral successional forests. However, S. argentea or S. sericans as one of dominants is only found in early or middle successional forests. As time goes by, the dominance of $S$. argentea and $S$. sericans would be replaced by their associated dominant taxa such as Castanopsis species (Supplementary Table S2).

In view of the potential effects of global climate warming on distribution, the Schima species under study may be forced to move to locations at higher latitudes or altitudes. Schima species in general have as strong dispersal capacity because of their lightweight and the fact that the seeds are wind-dispersed, so, they possibly can migrate to new sites. But they may not be able to evolve 
needed new adaptations to new localities in the time projected for a rapid climate change. Especially, Schima sericans endemic to NW Yunnan and SE Tibet and Schima villosa endemic to Yunnan and having a narrow distribution range will be greatly vulnerable under rapid global climate change.

\section{Conclusions}

Yunnan is found to harbor a high species richness and rarity-weighted richness of Schima. Canopy gaps created by moderate human and natural disturbances have supported Schima species' regeneration establishment in forming a mosaic of forest stand structure across the landscape in the subtropical zone of Yunnan. Some of the Schima species studied as a second dominant (rare as the top-dominant) present in the late-successional forests. Some of them are more often found as the top-dominant in early or middle successional forests, where as time goes by the dominance of Schima species would be replaced by associated dominant taxa such as Castanopsis species. Schima species can be used for restoration projects to restore native forests as part of the subtropical evergreen broad-leaved forest ecosystem.

\section{Supplementary information}

Supplementary information accompanies this paper at https://doi.org/10. 1186/s40663-020-00244-1.

Additional file 1. Supplementary Table S1. DBH-classes of species (IV $\geq 1.5 \%$ ) of each primary forest type.

Additional file 2. Supplementary Table S2. DBH-classes of major species (RIV $\geq 1.5 \%$ ) of each secondary forest type.

\section{Abbreviations}

DBH: Diameter at breast height; RIV: Relative importance value; SD: Standard deviation; H: Height

\section{Acknowledgements}

Not applicable.

\section{Authors' contributions}

C.Q.T. designed the study, analyzed the data and wrote the manuscript. P.B.H organized and analyzed the data. S.L. identified the botanical specimens. C.Q.T., L.-Q.S., P.-B.H., D.-S.H., Y.-F.L., M.-C. P., C.-Y. W., X.-S. L, W. L. and Z.-Y.Z. conducted the fieldwork. All the authors contributed discussion to improve the manuscript.

\section{Funding}

The study is financially supported by Ministry of Science and Technology, China (Project No.2015FY210200-15).

\section{Availability of data and materials}

The datasets generated and/or analyzed during the current study are not publicly available due limitation from the organization provided the research fund but are available from the corresponding author on reasonable request.

Ethics approval and consent to participate

Not applicable.

\section{Consent for publication}

Not applicable.

\section{Competing interests}

The authors declare that they have no competing interests.

\section{Author details}

${ }^{1}$ Institute of Ecology and Geobotany, College of Ecology and Environmental Science, Yunnan University, Kunming 650504, China. ${ }^{2}$ Research Institute on Resource Insects, Chinese Academy of Forestry, Kunming 650224, China. ${ }^{3}$ Caojian Forest Farm of Yunlong Forestry Bureau, Yunlong County 672711, Yunnan, China. ${ }^{4}$ Yunnan Academy of Forestry, Kunming 650201, China. ${ }^{5}$ Tibet Agriculture and Animal Husbandry College, Linzhi 860000, China.

Received: 23 January 2020 Accepted: 24 April 2020

Published online: 20 May 2020

\section{References}

Airy Shaw HK (1985) A dictionary of the flowering plants and ferns, 8th edn. Cambridge Univ Press, London

Bao WK, Liu ZG, Liu CL, Yuan YF, Liu RD (2000) Fifteen-year changes of tree layer in secondary Castanopsis-Schima humid evergreen broad-leaved forest in central subtropics of western China. Acta Phytoecol Sin 24(6):702-709

Bloembergen S (1952) A critical study in the complex-polymorphous genus Schima (Theaceae). Reinwardtia 2:133-183

Byng JW (2014) The flowering plants handbook: a practical guide to families and general of the world. Plant Gateway Ltd, Bradford

Cai F, Song YC (1997) A study on the structure and dynamics of Schima superba on Wuyi Mountain. Acta Phytoecol Sin 21(2):138-148

Cheng Y (2006) Characteristics of community and litter of mid-subtropical Schima superba and Pinus massonana plantations in restoration processes. Fujian Agricul For Univ, Fuzhou, Dissertation

Choi SK, Kim K, Jeong E-K, Terada K, Suzuki M, Uematsu H (2010) Fossil woods from the Miocene in the Yamagata prefecture, Japan. IAWA J 31(1):95-117

Da L, Yang YC, Song YC (2004) Population structure and regeneration types of dominant species in an evergreen broadleaved forest in Tiantong National Forest Park, Zhejiang Province, eastern China. Acta Phytoecol Sin 28(3):376-384

He J, Chen W, Li L (1998) Community diversity of the main types of the evergreen broad-leaved forest in the eastern part of the middle subtropical China. Acta Phytoecol Sin 22(4):303-311

$\mathrm{Hu} X$ (2005) Studies on the population ecology of Schima superba. Forestry College, Fujian Agric For Univ, Fuzhou, M.S. Thesis

Huang Q, Zheng Q, Xu J, Lin Y, Yao Y (1997) A study on the features of Schima superba Forest in Wanmulin nature reserve. J Fujian College For 17(1):42-46

Huang Z-L, Kong G-H, He D-Q (2000) Plant community diversity in Dinghushan nature reserve. Acta Ecol Sin 20(2):193-198

Jin ZX, Li J, Cai YL (2007) ISSR analysis of genetic diversity of Schima superba populations at different altitudes. Chin J Ecol 26(8):1143-1147

Kovar-Ender J, Hably L (2006) The flora of Mataschen-a unique plant assemblage from the late Miocene of eastern Styria (Austria). Acta Palaeobot 46(2):157-233

Lande R (1996) Statistics and partitioning of species diversity, and similarity among multiple communities. Oikos 76:5-13

Li L, Wei SG, Huang ZL, Ye WH, Cao HL (2008) Spatial patterns and interspecific associations of three canopy species at different life stages in a subtropical forest, China. J Integ Plant Biol 50(9):1140-1150

Li MM, Li JH, Tredici PD, Corajod J, Fu CX (2013b) Phylogenetics and biogeography of Theaceae based on sequences of plastid genes. J Syst Evol 51(4):396-404

Li Y, Awasthi N, Yang J, Li CS (2013a) Fruits of Schima (Theaceae) and seeds of Toddalia (Rutaceae) from the Miocene of Yunnan Province, China. Rev Palaeobot Palyn 193:119-127

Mai DH (1971) Uber fossile Lauraceae und Theaceae in Mitteleuropa. Feddes Repertorium 82(5):313-342

McCune B, Mefford MJ (1999) PC-ORD multivariate analysis of ecological data. MjM software design, Gleneden Beach

Min T, Bartholomew B (2007) Theaceae. In: Wu ZY, Raven PH (eds) Flora of China, vol 12. Science Press, Beijing and Missouri Botanical Garden Press, St. Louis

Myers N, Mittermeier RA, Mittermeier CG, da Fonseca GAB, Kent J (2000) Biodiversity hotspots for conservation priorities. Nature 403:853-858

Ohsawa M (1986) Distribution and succession of west Himalayan forest types in the eastern part of the Nepal Himalaya. Mount Res Devel 6(2):143-157

Pielou EC (1969) An introduction to mathematical ecology. Wiley, New York 
Prince LM (2007) A brief nomenclatural review of genera and tribes in Theaceae. J Syst Evol Bot 24:105-121

Prince LM, Parks CR (2001) Phylogenetic relationships of Theaceae inferred from chloroplast DNA sequence data. Am J Bot 88:2309-2320

Shi XG, Fu QY, Jin JH, Quan C (2017) Mummified Oligocene fruits of Schima (Theaceae) and their systematic and biogeographic implications. Sci Rep 7: 4009. https://doi.org/10.1038/s41598-017-04349-6

Song K (2007) Historical stand dynamics and disturbance history of an evergreen broadleaved forest dominated by Schima superba and Castanopsis carlesii, on Mt. Tiantong, East China. Master of science thesis. East China Normal University, Shanghai

Tang CQ (2015a) The subtropical vegetation of southwestern China: plant distribution, diversity and ecology. Plants and vegetation, vol 11. Springer, Dordrecht. https://doi.org/10.1007/978-94-017-9741-2

Tang CQ (2015b) Distribution patterns of the subtropical evergreen broad-leaved forests of southwestern China, as compared with the other regions of China. Collect Bot 34:e006. https://doi.org/10.3989/collectbot.2015.v34.006

Tang CQ, Chiou C-R, Lin C-T, Lin J-R, Hsieh C-F, Tang J-W, Su W-H, Hou X (2013) Plant diversity patterns in subtropical evergreen broad-leaved forests of Yunnan and Taiwan. Ecol Res 28:81-92

Tang CQ, Li T, Zhu X (2007) Structure and regeneration dynamics of three subtropical mid-montane moist evergreen broad-leaved forests in SW China, with special reference to bamboo in the forest understories. Can J For Res 37:2701-2714

Tripathi AK, Shankar U (2014) Patterns of species dominance, diversity and dispersion in 'Khasi hill Sal' forest ecosystem in Northeast India. For Ecosyst 1: 23. https://doi.org/10.1186/s40663-014-0023-2

Wang X, Li J (1999) Classification and succession of Schima superba forest in Guangxi. J Plant Res Environ 8(3):18-28

Wang Y, Tian L, Zhong L, Yang H, Jin H, Liu C, Li M, Chen J (2015) Community structure and species diversity of Schima superba-Pinus massoniana communities in Dongbaishan nature reserve. J Zhejiang Univ (Sci Edition) 42(1):038-046

Wangda P, Ohsawa M (2006) Structure and regeneration dynamics of dominant tree species along altitudinal gradient in a dry valley slopes of the Bhutan Himalaya. For Ecol Manag 230:136-150

Wei H (2017) Growth process and tree rings climatology of Schima superba in subtropical area of China. Master Thesis, Central South Univ For and Techn, Changsha

Williams P, Gibbons D, Margules C, Rebelo A, Humphries C, Pressey R (1996) A comparison of richness hotspots, rarity hotspots and complementary areas for conserving diversity using British birds. Conserv Biol 10:155-174

Wu ZY (ed) (1980) Vegetation of China. Science Press, Beijing

Xu XN, Wang Q, Hideaki S (2008) Forest structure, productivity and soil properties in a subtropical evergreen broad-leaved forest in Okinawa, Japan. J For Res 19(4):271-276

Yang YC, Da LJ, Chen B (2006) Population structure and spatial patterns for the main tree species in Castanopsis carlesii-Schima superba community in Tiantong, Zhejiang Province, China. Acta Ecol Sin 26(9):2927-2938

Yang YC, Zhuang P, Li XY (1994) A study on the Castanopsis platyacantha-Schima sinensis plant community on Mt. Emei Acta Phytoecol Sin 18(2):105-120

Zeng H, Hu TZ, Qi DH, He S (2010) Changes of death count and spatial distribution of tree layer of Schima argentea community in Jinyun Mountain Forest. Life Sci Res 14(5):402-408

Zhang P, Zhou Z, Jin G, Fan H, Hu H (2006) Genetic diversity analysis and provenance zone allocation of Schima superba in China using RAPD markers. Sci Silv Sin 42(2):38-42

Zhang W, Kan SL, Zhao H, Li ZY, Wang XQ (2014) Molecular phylogeny of tribe Theeae (Theaceae s.s.) and its implications for generic delimitation. PLoS One 9(5):e98133. https://doi.org/10.1371/journal.pone.0098133

Zhu Y, Zhao GF, Zhang LW, Shen GC, Mi XC, Ren HB, Yu MJ, Chen JH, Chen SW, Fang T, MA KP (2008) Community composition and structure of Gutianshan forest dynamic plot in a mid-subtropical evergreen broad-leaved forest, East China. J Plant Ecol 32(2):262-273

\section{Submit your manuscript to a SpringerOpen ${ }^{\circ}$ journal and benefit from:}

- Convenient online submission

- Rigorous peer review

- Open access: articles freely available online

- High visibility within the field

- Retaining the copyright to your article

Submit your next manuscript at $\boldsymbol{\nabla}$ springeropen.com 